Illinois State University

ISU ReD: Research and eData

Theses and Dissertations

3-19-2017

\title{
She Wanted It?: Examining Young Adult Literature And Its Portrayals Of Rape Culture
}

Katy Lewis

Illinois State University, kblewi1@ilstu.edu

Follow this and additional works at: https://ir.library.illinoisstate.edu/etd

Part of the English Language and Literature Commons

\section{Recommended Citation}

Lewis, Katy, "She Wanted It?: Examining Young Adult Literature And Its Portrayals Of Rape Culture" (2017). Theses and Dissertations. 693.

https://ir.library.illinoisstate.edu/etd/693

This Thesis is brought to you for free and open access by ISU ReD: Research and eData. It has been accepted for inclusion in Theses and Dissertations by an authorized administrator of ISU ReD: Research and eData. For more information, please contact ISUReD@ilstu.edu. 


\title{
SHE WANTED IT?: EXAMINING YOUNG ADULT LITERATURE \\ AND ITS PORTRAYALS OF RAPE CULTURE
}

\author{
Katy Lewis
}

\section{Pages}

At a time when discussions about rape culture appear throughout social media and the news, our ability to consider how literature addresses these social issues is critical. The recent work of scholars discussing rape culture emphasizes the crucial need to consider what many understand (though many also continue to dismiss or diminish) as a serious social issue. While these cultural critiques are worthwhile, my focus shifts these critiques from general (American) culture or society to a particular expression of culture: the young adult novel. In this thesis, I examine how this cultural discourse surrounding rape culture and its related myths appear in four young adult novels: Isabel Quintero's Gabi, A Girl in Pieces (2014), Laurie Halse Anderson's Speak (1999), Chris Lynch's Inexcusable (2005), and Courtney Summers's All The Rage (2015). Analyzing these novels, I explore how they attend to ideologies related to rape culture, and I argue that these novels complicate our understanding of rape culture and how this understanding reaches young adult audiences. While many forms of literature deal with aspects of rape culture, it is particularly important to consider how young adult texts address these issues because YA novels hold a special place in our culture as they are (often) the first texts written about the subject that young adults encounter. Moreover, even if young adults never encounter these texts, they are expressly marketed to a particular intended audience and hold particular explicit and implicit agendas, so there is a possibility these texts are either reacting to rape culture, perpetuating it—or both. The goal of my analysis is to illuminate the potential readings and 
consequences of young adult novels that portray rape. I further argue for putting these texts into conversation and under critical consideration, not banning, challenging, or censoring of such texts in any way, shape, or form.

KEYWORDS: Young Adult Literature, Rape Culture, Rape, Sexual Assault, Laurie Halse Anderson 
SHE WANTED IT?: EXAMINING YOUNG ADULT LITERATURE AND ITS PORTRAYALS OF RAPE CULTURE

\author{
KATY LEWIS
}

\author{
A Thesis Submitted in Partial \\ Fulfillment of the Requirements \\ for the Degree of \\ MASTER OF ARTS \\ Department of English \\ ILLINOIS STATE UNIVERSITY
}


(C) 2017 Katy Lewis 
SHE WANTED IT?: EXAMINING YOUNG ADULT LITERATURE AND ITS PORTRAYALS OF RAPE CULTURE

\author{
KATY LEWIS
}

COMMITTEE MEMBERS:

Karen Coats, Chair

Roberta Seelinger Trites 


\section{ACKNOWLEDGMENTS}

First, to my committee, Dr. Karen Coats and Dr. Roberta Seelinger Trites: your unending support and guidance along with your wise words and your endless encouragement have made writing this thesis overwhelmingly wonderful, and I will forever be grateful. To my mother, Donna Lewis, and my father, David Bryan Lewis, who always taught me to persevere even when things were hard: this thesis would never exist without you. To my best friends, Chrissy King and Lindsay (Graybill) Derby: you have been there from the beginning, when this thesis was only a small kernel of an idea, so thank you for staying with me throughout. And finally, to my master's cohort: you have been a joyous set of friends and an amazing source of brilliance. You make my brain hurt every day, and that will be infinitely meaningful to me.

K. L. 


\section{CONTENTS}

\section{Page}

ACKNOWLEDGMENTS

$\begin{array}{ll}\text { CONTENTS } & \text { ii }\end{array}$

CHAPTER I: INTRODUCTION 1

$\begin{array}{ll}\text { A Culture of Rape } & 1\end{array}$

Young Adult Literature and Discussions of Rape $\quad 5$

The Ethical Question in Young Adult Literature $\quad 8$

Investigating Four Novels: Gabi, A Girl in Pieces; Speak; Inexcusable; and All the Rage 10

CHAPTER II: A CONSIDERATION OF THE POLICING OF FEMININITY IN ISABEL

QUINTERO'S GABI, A GIRL IN PIECES AND LAURIE HALSE ANDERSON'S SPEAK 17

$\begin{array}{ll}\text { The Meaning of Femininity } & 17\end{array}$

The (Problematic) Construction of Sexual Agency 20

$\begin{array}{ll}\text { Considering Passivity } & 25\end{array}$

“[W]ell, they can kiss my ass" and "Let me tell you about it:" How These Novels End and

What That Means

CHAPTER III: THE POWER OF VICTIM BLAMING IN ACQUAINTANCE RAPE

SITUATIONS IN CHRIS LYNCH'S INEXCUSABLE AND COURTNEY SUMMERS'S ALL

$\begin{array}{ll}\text { THE RAGE } & 35\end{array}$

A Cultural Phenomenon: Acquaintance Rape, Victim Blaming, and The Consequences 35

Victim Blaming and Shaming: Did She Deserve It? (No. She Did Not.) 38

Considering Him: Acquaintance Rapists and Their Power 44

Reporting... and Its Consequences: The Work These Novels Do and Why It Matters 49 
WORKS CITED 


\section{CHAPTER I: INTRODUCTION}

\section{A Culture of Rape}

In 2013, college professor Laura Gray-Rosendale published a memoir about "the memory of a brutal sexual assault," in which she "recounts her long circuitous route from trauma to recovery" (“College Girl”). Notably, "the university’s administration, Gray-Rosendale feels, is, at best, indifferent to her plight" since "[h]er rapist, while not himself a Syracuse student, is a member of a prominent family of university donors" (Golden). In September 2014, USA Today reported that Emma Sulkowicz, a student at Columbia University, decided "[f]or her senior thesis" to "carry around a dorm-sized mattress for as long as she and her alleged rapist attend the same school; Sulkowicz developed this project after her rapist "was found 'not responsible' by Columbia University administration" (Deutsch). Two years later, CNN noted in June 2016 that "Widespread outrage has erupted over a California judge's decision to give a former Stanford University swimmer [Brock Turner] a six-month jail sentence for sexually assaulting an unconscious woman” because “"[a] prison sentence would have a severe impact on him,' [the judge Aaron] Persky said” (Fantz).

What do these three events have in common? They represent the pervasive nature of rape culture in American society.

When I use the term rape culture, I am specifically concerned with the many ways that most Western societies (and specifically American culture) conceptualize and discuss rape through a variety of mechanisms that affect how we view and respond to actual instances of rape. Kate Harding in Asking for It: The Alarming Rise of Rape Culture--and What We Can Do about It (2015) defines rape as: "A culture in which most victims of sexual assault and rape never report it because they fear they won't be believed - and know that even if they are believed 
they're likely to be mortified and harassed, blamed and shamed, throughout a legal process that ultimately leads nowhere" (1, emphasis added). In the events mentioned above, this certainly is the case. However, other complicated ideas, such as the constructions of masculinity and femininity and the reinforcement of such gender roles, also support the construction of rape culture. Together, these rape myths—as they are often referred to — create and reinforce rape culture. In this thesis, then, I will be examining how this cultural discourse surrounding rape culture and its related myths appear in four young adult novels: Isabel Quintero's Gabi, A Girl in Pieces (2014), Laurie Halse Anderson's Speak (1999), Chris Lynch's Inexcusable (2005), and Courtney Summers's All The Rage (2015). Analyzing these novels, I will explore how they attend to ideologies related to rape culture. I argue that these novels complicate our understanding of rape culture and how this understanding reaches young adult audiences.

The study of rape and rape culture has been increasingly discussed in the 2010s in various scholarly works. Kate Harding's previously mentioned Asking For It addresses cultural myths surrounding rape (such as miscommunication theory) and how pervasive they are regarding instances of rape by examining various ways that this occurs in culture, such as through the legal system (including both police interactions and legal cases), television, the internet, and the media. In doing so, Harding not only demonstrates how pervasive rape culture is, but she also provides potential solutions to these problematic ideologies even as she dismantles the system. In other scholarship, Carine Mardorossian theorizes the power dynamics of rape in her book Framing the Rape Victim: Gender and Agency Reconsidered (2014), "examin[ing] both how rape and victimization are culturally conceptualized today (in feminist theory, cinema, or fiction) and how these representations impact victims of violence and social responses to the crime" (17). By studying theory, cinema, and fiction, she further "examines how 
contemporary narratives of victimization are fundamental to the discourses of dominant masculinity that define U.S. nationalism" (22). Thus, Mardorossian reconsiders the way that society defines the characteristics of victimization, calling for careful attention to the way that such ideologies reinforce conceptualizations of masculinity and femininity as well as the idea of “rape as a woman or man's problem," rather than society's (130).

Taking another approach, legal scholar Jody Raphael, in her book Rape is Rape: How Denial, Distortion, and Victim Blaming Are Fueling a Hidden Acquaintance Rape Crisis (2013), historicizes scholarly work focused on cases of acquaintance rape and juxtaposes her own arguments about the social phenomena of victim blaming and victim shaming with stories from survivors of acquaintance rape. Raphael's book calls attention to the very real and very prominent experiences of acquaintance rape, despite how unsettling some critics find the topic as well as how other critics often deny the prevalence of acquaintance rape. In order to emphasize the importance of acquaintance rape as well as acknowledge its pervasiveness, Raphael cites in her book that, "In [Dean] Kilpatrick's general population sample in 2006, corroborated by the CDC study, only 11 percent of rapes were at the hands of strangers; 14 percent were boyfriends, 10 percent husbands and ex-husbands, 12 percent friends, 11 percent stepfathers, and 18 percent other relatives" (89, emphasis added). Raphael's work here emphasizes, despite the cultural myth that rapists are unknown assailants, how prevalent acquaintance rape is, which is especially notable since the four young adult novels examined in this project — and I would argue young adult novels more generally_-focus on acquaintance rape.

Some scholars have considered rape by theorizing rape prevention. In her article "Feminism, Foucault, and Rape: A Theory and Politics of Rape Prevention," Holly Henderson "envisions rape on a continuum of violence and takes as the beginning of that continuum the 
construction of the feminine body.... In articulating strategies that will prevent rape (that is, stop a rapist from successfully raping)," she continues, "this paper urges feminism to refocus on the earliest parts of the continuum" (Henderson 229). Using Foucault as the basis of her analysis, Henderson reconsiders any after-the-fact understanding of rape by thinking about the way that power structures instances of rape. In analyzing the body with Foucault's theory, Henderson thus proposes how we can prevent rape by breaking down the often repeated notion that "women [are] pre-constituted victims" (Henderson 226).

Similarly, Sharon Marcus focuses on the social structures that exist and reinforce the conditions for rape culture in "Fighting Bodies, Fighting Words: A Theory and Politics of Rape Prevention." She argues that we need to be critical of "rape scripts" that exist in society, a term that she says indicates how "rape [exists] as a scripted interaction which takes place in language and can be understood in terms of conventional masculinity and femininity as well as other gender inequalities inscribed before an individual instance of rape" (372). In critiquing these scripted interactions, Marcus's theory of rape prevention obliges us to break down the stereotypes and ideologies that affect people's responses to rape crimes when they occur and additionally obliges us to reimagine the female body as "neither raped nor inherently rapable" (Marcus 370). Such stereotypes and ideologies include that men rape because they are biologically equipped to do so (370); that the court system positions the prosecution of rape after-the-fact, which "has limited effectiveness for a politics of rape prevention" (370); that “[a]ttempts to stop rape through legal deterrence fundamentally choose to persuade men not to rape," which goes back to the point about men raping because they simply can (371, emphasis in original); and that, more generally "women are rapable, women deserve rape/women provoke rape, women want rape, women are ashamed of being raped/women publicly lie about being 
raped" (371). Marcus's critique of such ideologies and stereotypes urges us to revisit our understandings of rape and "to treat it as a linguistic fact: to ask how the violence of rape is enabled by narratives, complexes and institutions which derive their strength not from outright, immutable, unbeatable force but rather from their power to structure our lives as imposing cultural scripts" (371, emphasis in the original). In doing so, Marcus suggests, we can begin to theorize a politics of rape prevention, rather than perpetuating the idea that women are always already rapable or that we can only deal with rape after it has occurred.

The work of these scholars emphasizes the critical need to consider what many understand (though many also continue to dismiss or diminish) as a serious social issue. Examining culture more broadly and theorizing about the ideological effects on instances of rape brings awareness to an issue gaining attention in the media, such as the Columbia and Stanford cases I mentioned previously. While these cultural critiques are worthwhile, my focus shifts these critiques from general (American) culture or society to a particular expression of culture: the young adult novel. In doing so, my goal is to illuminate the potential readings and consequences of young adult novels that portray rape. Furthermore, I want to stress that, in illuminating such issues, I argue for putting these texts into conversation and under critical consideration, not banning, challenging, or censoring of such texts in any way, shape, or form.

\section{Young Adult Literature and Discussions of Rape}

Some scholarship has already begun to consider the overlap between young adult literature and rape. In their 2014 article, "Critical Representations of Sexual Assault in Young Adult Literature," Erika Cleveland and Sybil Durand "examine representations of sexual assault in four YA texts and discuss the implications these have for education" in order to think about "how young adult literature (YAL) engages the national discourse on rape and how teachers 
might facilitate critical discussions about sexual assault with their students" (Cleveland and Durand). While Cleveland and Durand consider the overlap of rape and young adult literature, my analysis of young adult literature focuses more on the patterns of rape culture that I have noticed in YA novels and their potential implications in the field of young adult literature. Furthermore, Cleveland and Durand focus on educational implications within young adult literature in order to contemplate what these novels teach adolescents whereas I will consider the literary implications of such novels by exploring how discussions of rape occur in young adult novels. Typically, discussions of rape seem to be explicit: a reader might find characters that are expressly confronting or discussing rape (such as protagonists or supporting characters who have been raped). These texts often portray victims responding to their rapes, victims figuring out how to talk about their trauma, and people more generally reacting to the rape, victim, and rapist. In studying these literary patterns, I will also analyze the ideological implications of such patterns, an area that Cleveland and Duran do not fully explore.

Another scholar, Marion Rana, studies the connection between rape and young adult literature in "Sexual Violence and Rape Myths in Contemporary Young Adult Fiction." Rana explores "how sexual violence is a recurrent theme in young adult fiction and that different rape myths are employed to justify sexual violence against women" (168) and mainly focuses on two young adult vampire series—L. J. Smith's Vampire Diaries and Stephenie Meyer's Twilight series - to think about rape myths, using Martha R. Burt's work as the basis of her analysis. While Rana emphasizes rape myths in vampire fiction, she also theorizes potential implications for young adult texts from other genres, such as Suzanne Collins's dystopic The Hunger Games and Sue Limb's comedic Girl, 15, Charming but Insane. Rana's focus considers rape myths appearing in young adult literature more broadly as a way to think about literature as a cultural 
object, but she does not explore novels that contain rape scenes or discussions of rape. Vampire Diaries, the Twilight series, The Hunger Games, and Girl, 15 are novels that "reproduce societal concepts of sexualized violence unreflectedly" (177). Conversely, I analyze novels that contain specific references to rape in order to think about how young adult novels are explicitly addressing rape. Oftentimes, character responses to rape may reinforce gender norms (especially concepts of femininity and masculinity) even as they attempt to subvert other troublesome beliefs about rape. While I do not automatically characterize such ideologies about gender negatively or problematically, I assert that these novels (as is typical in our culture) equate femininity with cisgender females and masculinity with cisgender males and that such essentializing notions of gender-in particular, I am concerned with femininity and its policing — contribute to rape culture. One (and perhaps the most prominent) aspect of masculinity is tied up in the idea of dominance, while femininity is often equated with passivity. Men, for instance, are expected to assert their dominance in various aspects of their life; accordingly, women should remain passive subjects.

Aiyana Altrow's article, “Rape Scripts and Rape Spaces: Constructions of Female Bodies in Adolescent Fiction" argues that young adult novels that do not include or fully characterize a rapist in the novel "results in a focus on and pathologising of female characters" (50). Exploring how four young adult novels-Colleen Clayton's What Happens Next, Julie Berry's All the Truth That's in Me, Jenny Downham's You against Me, and Daisy Whitney's The Mockingbirdsportray females' relationships with their bodies, food, and clothing, Altrow concludes that "[t]hese representations are ideologically problematic, as they locate rape inside the bodies of girls and women" (63). While Altrow's points about rape scripts and rape spaces are both salient and poignant, her focus on these aspects of the novels differs from my analysis of the discourse 
more generally represented by the characters as well as my analysis of rape myths in the novels I will explore.

I would like to additionally note that I do not think that these texts exist as binaries; these texts are not either perpetuating or undermining rape culture. Often, they are doing some of each. Furthermore, while rape victims are not solely categorized as women, I am focused on rape culture and how it works on those who identify as women for the scope of this project since considering rape culture's effects on both women and men as victims would necessitate a longer exploration than this thesis can attend to. With that said, I want to note that there is still a lot of work to do in the field as to how rape culture affects men as victims.

\section{The Ethical Question in Young Adult Literature}

The fact that these novels discuss rape and rape culture warrants further examination because they are specifically marketed to young adults. Many scholars in children's and young adult literature have stressed the importance of considering the ethical effects of writing for young audiences. For example, Mike Cadden in his article "The Irony of Narration in the Young Adult Novel" discusses the inherent irony that exists when an adult author attempts to create an authentic voice of a young adult narrator and how the author has a duty to ethically attend to this irony, "providing that reader [with] the tools for identifying potentially debilitating world views in the text" (153). This ethical consideration of narrative techniques works to call attention to the power that authors hold over novels and potentially their readers, a process necessary when thinking about novels that contain difficult topics, such as the ones that I explore.

Similarly, Anita Tarr considers the moral implications of Robert Cormier's The Chocolate War as an iconic young adult text in her article "The Absence of Moral Agency in Robert Cormier's The Chocolate War." Tarr's discussions of moral agency criticize Cormier's 
writing and his failure to provide characters that "are aware that they are making moral decisions that have far-reaching consequences" (121). Furthermore, her criticisms of Cormier highlight the critical attention paid to the role of authors creating (often) controversial young adult texts. In both Cadden's and Tarr's scholarship, ethical considerations of the messages and ideologies that readers are encouraged to take away from such texts emphasize that these types of readers are still learning about the world and that the ethical responsibility of authors involves encouraging readers' critical consideration of the dilemmas found in the texts that they are reading.

Moreover, such scholarly work as the edited collection Ethics and Children's Literature (2014) showcases a variety of ways to attend ethically to the topics found in children's and young adult literature. Relevant scholarship found in this volume includes Mary Jeanette Moran's “Making a Difference: Ethical Recognition through Otherness in Madeleine L'Engle's Fiction," which examines L'Engle's novels through a feminist relational ethics framework to theorize how difference is characterized. In "Heeding Rousseau's Advice: Some Ethical Reservations about Addressing Prejudice through Children's Literature," Claudia Mills considers the question, "What if some of our best intentioned attempts at shaping children through story actually backfire and produce results directly contrary to those at which we aim?" (181). More generally, Mills notes in the introduction to the collection that "[t]he purpose of this collection is to examine the range of ways in which children's literature tries to communicate values to children, motivate them to obey moral rules, and shape the kinds of persons they are in the process of becoming and the kind of world they will grow up to create" (Introduction 1).

While the ethical questions addressed in the previously mentioned scholarship do not focus on young adult literature dealing with rape culture, they certainly create a framework within which we can consider young adult texts more generally. 


\section{Investigating Four Novels: Gabi, A Girl in Pieces; Speak; Inexcusable; and All the Rage}

Influenced by the work of such scholars as Harding, Mardorossian, and Raphael, I

examine how young adult (YA) literature addresses, perpetuates, and occasionally undermines aspects of rape culture. At a time when discussions about rape culture appear throughout social media and the news, our ability to consider how literature addresses these social issues is critical. While many forms of literature deal with aspects of rape culture, it is particularly important to consider how young adult texts address these issues because YA novels hold a special place in our culture as they are (often) the first texts written about the subject that young adults encounter. Moreover, even if young adults never encounter these texts, they are expressly marketed to a particular intended audience and hold particular explicit and implicit agendas, so there is a possibility these texts are either reacting to rape culture, perpetuating it—or both.

The four novels examined in this thesis certainly do not represent all YA novels that address or portray rape and/or rape culture. However, they do take on this phenomenon in different ways; thus, I can more broadly consider how different YA novels involving rape work narratively. In general, I analyze these texts by examining what they set out to do, what they actually do, what the intended audience is left with, and, in the end, why that matters. The framework of my analysis begins with understanding rape culture (as previously noted, I mainly use Harding's definition of rape culture) and how it is subtly perpetuated throughout cultural products and dominant ideologies. My analysis of these novels then focuses on characterization in the novels: I examine both how the characters speak and act about issues related to rape culture. Since characterization in the novels is never straightforward—especially since characters may say one thing but do another-I identify where the texts explicitly communicate one thing as important but implicitly indicate another. In Laurie Halse Anderson's Speak, for instance, 
Melinda struggles with the trauma of her rape and attempts to establish a way to communicate this trauma as part of her healing process. At the same time, Melinda brutally criticizes other females in the novel for their own sexual agency. Since female sexual agency is often used to blame victims for what occurred to them, this disconnect between what the text wants readers to critically think about and what the text itself is perpetuating is significant. In such a moment, I analyze how these texts deconstruct themselves in the ways that they attempt to address rape culture.

Chapter 2, “A Consideration of The Policing of Femininity in Isabel Quintero's Gabi, A Girl in Pieces (2014) and Laurie Halse Anderson's Speak (1999)," analyzes two young adult novels that highlight the policing of femininity as a major way of discussing rape and rape culture. Utilizing such scholars as Harding, Mardorossian, Sharon Marcus, Sandra Bartky, and Holly Henderson, I explore an inherent contradiction in the process of policing femininity: passivity is a defining characteristic of femininity yet women are required to actively protect themselves (i.e. the concept that they should not wear certain things to provoke negative attention or appear as if they were 'asking for it' in any way). Furthermore, I analyze how femininity is constructed, how femininity is often equated with cisgender females, and how femininity is maintained through a process which I theorize further as policing.

For this chapter, I have chosen to analyze Gabi, A Girl in Pieces and Speak because they express conceptualizations of femininity most vocally of all the novels I am considering. Gabi, A Girl in Pieces especially stands out because, unlike Speak and Courtney Summer's All the Rage (a novel I analyze in Chapter 3), it involves Gabi standing by her friend Cindy who is raped by her then-boyfriend. Since the instance of rape differs from the other novels discussed in my thesis, I want to note that the instance of rape in Gabi, A Girl in Pieces is not the main focus of 
my analysis. Rather, I am most interested in how the novel portrays how Gabi begins to acknowledge the unfair biasing against women in our society that maintains that it is a woman's job to keep from being raped or from being taken advantage of sexually; the rape of Cindy is a small part of the conversation. These discussions in the novel (of the rape of Cindy and of sex in general) culminate in a larger consideration of how dangerously rape culture works to indoctrinate individuals. Even more notably, Quintero's novel focuses on important issues such as a female's sexual agency as Gabi comes to terms with her own desires and how they inform her own sexual practices, regardless of the outrage of her family members. The novel's conversations about sexual agency, femininity, and rape reveal how the novel works to break down many of the rape myths that Kate Harding discusses in Asking for It as well as the dangerous constructions of femininity that inform the discourse of rape culture, especially that which has been described by scholars such as Holly Henderson, Sharon Marcus, and Sandra Bartky.

In selecting texts for this my thesis, I would be remiss not to include Laurie Halse Anderson's Speak (1999) since it is a novel that many have pointed to since its publication as a way to discuss rape. In analyzing Speak, my analysis points out that, while the positive work that Laurie Halse Anderson's novel Speak sets out to do-encouraging women to speak out about sexual assault, rape, and trauma—is commendable, the novel ultimately undermines these message by its unwitting adherence to ideals that make rape culture possible. In keeping with analyzing how rape culture works by policing femininity, I argue that Melinda's critical assessment of her female classmates undercuts the progressive nature of the rest of the novel. If a novel like Speak is attempting to participate in a necessary conversation about an atrocious violence, then that novel's inclusion of judgmental assessments of female bodies and emphasis 
on a culture of fear hinders the novel's attempt to participate in such a conversation. Speak does not critically address any of Melinda's fears, especially her fear of not being believed about her rape, and the novel ends with the assumption that speaking about the trauma is enough. ${ }^{1}$

In analyzing the implications of how both Gabi, A Girl in Pieces and Speak end, I assert that Gabi, a Girl in Pieces undermines passive indoctrination into rape culture by portraying a young girl who learns to assert herself, while Anderson's Speak gives voice to a prominent issue in our culture while unwittingly perpetuating rape culture myths.

In Chapter 3, "The Power of Victim Blaming in Acquaintance Rape Situations in Chris Lynch's Inexcusable and Courtney Summers's All the Rage," I explore acquaintance rape as a particular aspect of rape culture and how it affects victims who are women. Utilizing such works as Andrew Taslitz's Rape and the Culture of the Courtroom and Jody Raphael's Rape is Rape: How Denial, Distortion, and Victim Blaming Are Fueling a Hidden Acquaintance Rape Crisis, this chapter focuses on the concepts of victim blaming and shaming as well as acquaintance rape and how these concepts are navigated in two YA novels: Chris Lynch's Inexcusable and Courtney Summers's All the Rage.

I chose Inexcusable and All the Rage because they approach the topic of acquaintance rape differently even as they both consider how people react to this type of crime. Lynch's Inexcusable takes Keir Sarafian's - the rapist's - perspective, chronicling the events that precede him raping Gigi Boudakian as well as his reactions to Gigi’s accusation. Unlike the other novels

\footnotetext{
${ }^{1}$ I would like to note that in Melinda's case, that may be perfectly true, and how
} individuals decide to work through their traumas is individually significant and valid. However, the novel does not attempt to consider why working through her trauma this way is enough for Melinda. Instead, it portrays her speaking out as the catalyst for her healing. 
analyzed in my thesis, the protagonist of Lynch's book is not a victim but a rapist, which produces a completely different type of analysis. In a significantly different way, Romy Grey narrates Summers's All the Rage, a novel focused on the aftermath of Romy accusing the sheriff's son, Kellan Turner, of rape and how her peers and the rest of town turn against her. The narrative structure of Romy's story grips readers and illustrates typical reactions to rape accusations when the victim knew their attacker.

Kate Harding's questions of how we criminalize rape victims and belittle the gravity of acquaintance rape provide an interesting way to consider the work that Inexcusable and, especially, All the Rage do. She asks,

Why else would we spend so much time assessing the victim's behavior, trying to determine to what degree she invited the crime? Why do we demand to know if the victim physically fought his attacker, if he has bruises and scrapes to prove it? Why are we so ready to believe that the rapist was just a well-meaning young man who got confused by "mixed signals"? (Harding 11) Along with Harding's examination of acquaintance rape, I use Andrew Taslitz's Rape and the Culture of the Courtroom, in which he explores how rape culture surfaces in the courtroom by examining language, specific cases, and legal practices; and Jody Raphael's Rape is Rape: How Denial, Distortion, and Victim Blaming Are Fueling a Hidden Acquaintance Rape Crisis, in which she analyzes situations of acquaintance rape and discusses the social reactions to acquaintance rape; to analyze how these novels undermine the denial of acquaintance rape and of the very real, lived experience of rape victims.

Ultimately, these novels recognize the rape victims' voices and their right to make that voice heard. Utilizing these theorists, I consider how Lynch's and Summers's novels do 
important work to help dismantle some of the negative stigmas surrounding acquaintance rape. Even though Romy is condemned for speaking up in All the Rage, it is the novel's closing scene in which Romy's condemner recognizes and accepts that Romy is telling the truth that indicates that silence is not the only choice and that silence is not a role for which one has to be condemned. ${ }^{2}$ In Inexcusable, Gigi, too, speaks up, and while Keir desperately tries to silence her, she will not be silenced. I conclude by theorizing about the implications of how these novels end: Lynch's Inexcusable makes some good strides to deflate the concept of the rapist as "just a good guy," and Summers's All the Rage unpacks a lot of complicated issues characterized by both rape culture and acquaintance rape.

My conclusion explores the implications of the texts I analyzed in Chapters 2 and 3 more specifically as part of the ethical conversation in young adult literature, and I evaluate the work that these novels do to disassemble some of the ideas that make rape culture possible in light of the intended audience for these two genres: young adults and children. In conversation with the scholars of YA literature that I have worked with throughout my analysis, I further consider why the deconstruction of such texts matters in the context of children's and young adult literature as a scholarly field. I argue that representations of rape that do not wholly reaffirm problematic notions of rape culture deserve recognition since we are marketing these novels specifically to young audiences who may or may not be having the necessary conversations about rape culture. Moreover, novels that are praised for their abilities to bring awareness to the issue of rape culture but in the end undermine the work they attempt to do deserve further critical attention. If, in some novels, certain deconstructive moments show the text trying to be progressive but only

\footnotetext{
${ }^{2}$ This, if further explored, could also be problematic because it reasserts the idea that the victim's story must be vetted, rather than simply taken as truth.
} 
succeeding in reaffirming problematic ideals, the reader can be left with an overarching message that reinscribes aspects of rape culture. Thus, our ability to understand these moments of tension is important because that understanding, explored in conversation with teen readers, would help remove some of the power of a text that may on the surface appear exemplary. This is especially notable if these texts are being handed to children or young adults as ways to teach them about social issues (as they so often are). 


\section{CHAPTER II: A CONSIDERATION OF THE POLICING OF FEMININITY IN ISABEL QUINTERO'S GABI, A GIRL IN PIECES AND LAURIE HALSE ANDERSON'S SPEAK}

\section{The Meaning of Femininity}

Sharon Marcus notes in her article "Fighting Bodies, Fighting Words: A Theory of Rape Prevention" that "Rapists do not prevail simply because as men they are really, biologically, and unavoidably stronger than women. A rapist follows a social script and enacts conventional, gendered structures of feeling and action which seek to draw the rape target into a dialogue which is skewed against her" (372, emphasis added). Rape, therefore, is not about biology but instead about culturally constructed myths, especially those about femininity and masculinity. Furthermore, as Holly Henderson asserts in "Feminism, Foucault, and Rape: A Theory and Politics of Rape Prevention" that: "[r]ape is not simply a matter of violence. Rather, it is a concrete example of generated violence that reinforces social scripting and gender oppression" (249). We can acknowledge that women and men are both interpellated into these ideologies about gender that reinforce dangerous notions of gender that make rape culture possible. However, I want to clarify that my main focus for this chapter is how rape culture affects women, and more specifically, teenage girls. ${ }^{3}$ Society indoctrinates young girls into passivity as a fundamental part of femininity. At the same time that we compel passivity onto young girls, we blame them for not being active or reactive enough in certain situations, and it is this ideology that produces rape culture.

Rape culture exists because rape, as a crime, ends up being about the victim's actions. Harding explains:

\footnotetext{
${ }^{3}$ Rape victims are not just women, and more work still needs to be done on how rape
} culture affects victims that are men. 
If the real crime of rape is the violation of another person's autonomy, the use of another person's body against their wishes, then it shouldn't matter what the victim was wearing, if she was drinking, how much sexual experience she's had before, or whether she fought hard enough to get bruises on her knuckles and skin under her fingernails. What matters is that the attacker deliberately ignored another person's basic human right to determine what she does with her own body. It's not about sex; it's about power. (12, emphasis added)

Unfortunately, what Harding gets at with the use of "shouldn't matter" is that these things $d o$ matter for society. These are the questions rape victims (especially women) face. Furthermore, this incessant line of questioning of the victim — and not the perpetrator — characterizes, for Harding, how "[r]ape is perhaps the only perpetratorless crime, in our collective imagination" (36). Many times we, as a society, cannot let go of the idea that an individual could not have done this, so instead we blame the victim. Moreover, "This ubiquitous idea that by controlling our behavior, appearance, and whereabouts we can keep ourselves from being raped does nothing to help women (let alone potential victims who aren't women)" (Harding 33). These attitudes set up an unwinnable situation: girls can and will never do anything to protect themselves or avoid assault, which somehow already makes them victims. Because of this, we criticize their sexual agency and desires: we police them. Marcus argues against this idea "of seeing rape as the fixed reality of women's lives, against an identity politics which defines women by our violability" (370). At the same time that we tell girls to remain passive, we also assert that girls need to be the ones actively policing themselves.

In the sense that Sandra Bartky describes in her article "Foucault, Femininity, and the Modernization of Patriarchal Power," members of society indistinctly perpetrate this policing. 
Notably, "The disciplinary power that inscribes femininity on the female body is everywhere and it is nowhere; the disciplinarian is everyone and yet no one in particular" (Bartky 36, emphasis added). While we can momentarily pinpoint individuals who police women, holistically, society is responsible for this discipline of the cis-female body. ${ }^{4}$ I will focus on how the policing of femininity occurs in two young adult novels: Isabel Quintero's Gabi, A Girl in Pieces and Laurie Halse Anderson's Speak. Even though we can conceptualize the discipline of the female body in a variety of ways, I am particularly interested in how policing occurs through ways that characters respond to women's sexuality in these two narratives that focus on instances of rape.

While Gabi, a Girl in Pieces and Speak both involve rape and rape culture, they do so in vastly different ways. In Quintero's novel, Gabi, a senior in high school, must confront her own understandings of what it means to be a woman and, consequently, how she is supposed to act as a woman. The rape of Gabi's best friend, Cindy, and her resulting pregnancy underscore the novel's larger consideration of rape culture. In particular, the novel positions the opinions of Gabi's mother, aunt, and best friend about femininity in opposition to Gabi's own sentiments, which she develops over the course of the novel. In the end, Gabi, a Girl in Pieces rejects the passivity so often acquainted with rape culture since Gabi gains her own agency and independence and decides to stand up for herself. Conversely, Speak explores rape culture

${ }^{4}$ Since the characters who are raped in the two novels discussed in this chapter are girls, I am focusing on femininity, its equation with cisgender females, and the way that rape culture always already constructs women as victims. However, I recognize that this focus can be restrictive since, as Kate Harding indicates, "Anyone can be raped" (5). Like Harding, though, I believe that women are often "the ones asked to change our behavior, limit our movements, and take full responsibility for the prevention of sexual violence in society" (5). 
through a narrative about rape victim Melinda's freshman year of high school. As the novel's title suggests, Melinda must learn how to speak about what has happened to her. However, Melinda's newfound ability to voice her trauma does not indicate that Melinda has considered, like Gabi has, the societal constructions that make rape culture possible or that made her feel like she could not speak about her experience. The novel, through its single-voiced discourse, reinforces some questionable aspects of rape culture even as it undermines others. Moreover, especially important to consider are the female communities in the school—Rachel and Melinda's old friends, the lacrosse team-which demonstrate how the book knows and understands more than Melinda does about what is at stake in rape culture.

\section{The (Problematic) Construction of Sexual Agency}

The main way that femininity is monitored in Gabi, A Girl in Pieces is through characters who attempt to regulate female sexual agency. While Gabi later in the novel critiques the way society constructs women's sexual agency, her original indoctrination into this mindset rings clear at the beginning of the novel. Gabi begins talking about sex on the first page of the novel, pointing out, “I don't necessarily agree with that whole wait-until-you're-married crap though. I mean, this is America and the twenty-first century, not Mexico one hundred years ago. But, of course, I can't tell my mom that because she'll think I'm bad' (1, emphasis added). Here, Gabi has clearly internalized the doctrine that her mother (and later aunt) spout throughout the novel. The narrative again links this association between women and badness when Gabi finds out that Cindy might be pregnant. Gabi narrates,

I was so pissed at the situation. Pissed and disappointed. Not at the fact that she had sex, but that she hadn't been careful. That she had just become another statistic: Hispanic Teen Mom \#3,789,258... We had even criticized the girls who 
showed and called them stupid. "When we have sex, we'll use a condom." We had been so sure about it. (5, emphasis added)

Gabi is not concerned that, together, German and Cindy have not been careful. Rather, she places the blame on Cindy, even pointing out how they have ridiculed other girls who had been so stupid. (It is notable, too, to point out that, at this point in the novel, Gabi does not know that German has raped Cindy because Cindy does not tell her until much later.) As is often the case, the responsibility of sexual activity is placed on the woman. As the novel progresses, the narrative begins to juxtapose this indoctrination with Gabi's growing awareness of how unfair societal expectations about women are. While we experience more characters in the novel who are focused on policing femininity than we do characters who question dominant notions about femininity, the first person narrative style encourages us to support Gabi's.

Gabi's mother and aunt both, to some degree, participate as disciplinarians of Gabi's femininity, which occurs by mainly deemphasizing Gabi's sexual agency. The novel opens with a discussion of the limitations of Gabi's sexual education: "Every time I go out with a guy, my mom says, 'Ojos abiertos, piernas cerradas.' Eyes open, legs closed” (1). Gabi's mother constantly critiques and worries about Gabi's sexual practices. Her preoccupation with legs remaining closed (specifically, Gabi's legs remaining closed) reifies a harmful notion about women that makes rape culture possible. In her essay "Fighting Bodies, Fighting Words: A Theory and Politics of Rape Prevention," Sharon Marcus critiques a postmodern notion that "rape has always already occurred and women are always either already raped or already rapable" (Marcus 369). This notion - if women are already rapable — then leads to the idea that it is a woman's duty to protect her body. More important, this notion informs the indoctrination of passivity. Harding asserts "that as women, we've been taught never to rule out the possibility [of 
assault]. We've been taught that it's never safe to assume we'll be perfectly fine, walking around our own neighborhoods after dark, like normal people" (30). Therefore, women should not insert themselves into situations which might lead to an assault; instead, it is important for women to remain passive and not draw attention to themselves so that they will not be raped. Harding states, "Rape is presented as an abstract threat to women the way climate change is a threat to the earth - a frightening specter we all live with, and we must change our own behavior in hopes of warding it off, but you can't really pin it on anyone in particular" (36). The threat of rape, apparently, exists inherently in a woman's body. Rather than recognizing the reality of this threat and holding perpetrators of rape accountable, "we," as Gabi acknowledges, "are raised to believe that it is our job and responsibility to protect our bodies and if something goes wrong, we are always at fault, even if it's rape" (Quintero 198).

However, this logic is inherently flawed—even as it (supposedly) becomes the truth of women's lives. ${ }^{5}$ If a woman is always already rapable, then the idea of protecting oneself is almost absurd. Following this logic, then, there is nothing one can do to protect oneself from rape, which inherently characterizes woman as passive victims. In this moment, though, rape culture still places the impetus of protection on women - that they are in charge of protecting themselves—which means we believe this flawed "always already victim" logic. Individuals in society that perpetuate rape culture often implicitly (and explicitly) tell women to wear certain things and to not wear other things and to act certain ways and to stop acting other ways. Overall, this particular part of society still points to women to police themselves - to actively try not to be

\footnotetext{
${ }^{5}$ I would like to note here that I do not personally believe this, but I think it is important
} to think through the logic often utilized by those who employ or adhere to ideologies that are a part of rape culture. 
rape victim, even if logic (apparently) already says otherwise. Altogether, these beliefs train women to be passive creatures in all areas of their lives: asserting oneself (supposedly) leads one to harm. Because of this, passivity as a notion of self-preservation often comes at the cost of women's sexual agency. Women who have sexual agency and assert this agency are often condemned as whores. Therefore, a woman cannot assert her sexual agency without being a whore. For instance, if she does not want to be seen as a whore, she cannot assert her sexual agency by indicating that she wants sex. In this situation, a woman can only be a passive receiver of sex-at least, this is what society tells us.

Throughout the novel, Gabi is led to believe that any sort of sexual agency makes a woman bad and is something to be ashamed of. When Cindy reveals that she is pregnant, Gabi's mother goes on a long rant about how "I don't want you to talk to her anymore. She'll give you bad advice and convince you to do the same thing she did, and then you'll go and open your legs for everybody... You know who I feel sorry for? Her mom" (Quintero 14). Whether she realizes it or not, Gabi's mother invests in this notion of fear when she mistrusts Gabi's ability to utilize her own sexual agency, assuming that Gabi—just like Cindy, just like all girls——will make the same ("bad") choices. This policing of Gabi occurs again when tía Bertha comes to stay with them in order to help with her brother's (Gabi's father's) addiction. When Gabi makes the decision to buy condoms in case she and her boyfriend Martin decide to have sex, tía Bertha sees her at the drug store and confronts her the next day.

Don't worry, I'm not going to tell your mom. That's your business. I admire that you are being careful and protecting yourself. Very smart. ... But I want you to remember that God will know. He will know what you did... or what you do. He knows every sin you commit, and he will be watching you. I want you to be 
thinking about that tonight before you do any cochinadas that might condemn you to Hell. Because you don't want to go to Hell, mi'ja. Do you? (Quintero 239) In the same breath that tía Bertha recognizes and appreciates Gabi's sexual agency (a rare but triumphant moment in a novel whose main female characters, besides Gabi, condemn each other for any hint of sexual agency), tía Bertha tries to obliterate any positive connotations of Gabi’s sexual agency in an attempt to make her more passive. ${ }^{6}$

Perhaps the idea is that women having sex are more likely to be raped, or that women who are assertive, who make it known that they enjoy sex or have any sort of sexual agency, are better targets for rape. If a woman has ever asserted her sexual agency, then, “[b]ecause [her] vagina is open for business, it's not like having a penis in there is anything new or shocking!" (Harding 12). Gabi critiques this notion, too. "Being a virgin," Gabi says, "can't be the only thing that makes you a 'nice young lady' because I know plenty of girls who are virgins, but could never be called nice-young-anythings because they are straight-out spawn of Satan"; Gabi says that "the untouched hymen," though, "is one of the requirements, [her] mother has insisted, that is inherently present in the anatomy of a nice young lady" (Quintero 269). Virginity as a marker of goodness has further implications for the rape myth "She asked for it." As Harding stresses, "It is literally impossible to ask for rape. Rape, by definition, is sex you did not ask for.

\footnotetext{
${ }^{6}$ Notably, there is an alternate reading here which can be framed in a religious context. For Gabi's mother and aunt, who come from a religious perspective, refraining from sexual activity does not make one passive; instead, one is actively resisting the cultural standard that sex prior to or outside of marriage is acceptable. However, Gabi does not see the standard through the same religious perspective, which is why my reading focuses on how Gabi understands her aunt's comments.
} 
So either you mean that a woman who dresses a certain way, or flirts, or otherwise expresses her sexuality on her own terms somehow deserves to be raped - which would make you a monsteror you are wrong, and she was not asking for it" (24, emphasis added). Since rape culture often encourages scrutinizing rape victim's stories, any sign of sexual agency or activity (e.g. this woman was not a virgin) somehow undermines the victim's claim — as if being sexually active or assertive automatically makes one more likely to be raped. While we can conceptualize this policing as an example of self-preservation, indoctrination into passivity convinces women that they should not and do not need to have sexual agency and that having sexual agency (versus being passive or committed to a religious position that limits sexual activity to marriage) makes a woman bad.

\section{Considering Passivity}

Conversely, Melinda exemplifies the self-policing and passivity often associated with being feminine and the internalization of fear inherent in rape culture. Moreover, her reactions to her rape exemplify the culture of fear and shame that has indoctrinated her after her rape. For instance, when skipping school and spending the day in the hospital, Melinda considers the patients who have been admitted: "There is nothing wrong with me. These are really sick people, sick that you can see" (Anderson 113, emphasis added). Perhaps we are supposed to read this knowing that Melinda's process, while it has been detrimental to her mental health for a lengthy period, allows her to heal in her own way. Maybe we are supposed to recognize how far she has come in the most clichéd sense. Regardless, the message that dealing with a sickness that one cannot see is not actually sickness — or at least it is not as important as a sickness that is visibly written on the body—is problematic since it represents how Melinda's fear causes her to be passive in recognizing her trauma. 
The section entitled "STUPID STUPID” invokes rape culture's notion of fear through the two warring parts of Melinda's personality_Melinda \#1 and Melinda \#2. In her mind, they battle over Melinda's decision to not go to the party that David, a classmate, invited her to. Melinda \#1 states that David "wasn't going to try anything. His parents were going to be there! You worry too much. You're never going to let us have any fun, are you?” (Anderson 132). Melinda \#2 overrides Melinda \#1, saying, “The world is a dangerous place. You don't know what would have happened. ... Assume the worst. Plan for disaster" (Anderson 132). Melinda \#2 represents the sense of fear that hangs over many women - the fear that they will be raped. However, Speak conceives of this indoctrination occurring after the fact; the novel shows a clear difference between Melinda's willingness to party before her rape (she enjoys drinking and dancing at the party) versus after her rape (she is more anxious, which the two Melindas represent). Melinda believes on some level that because she could not speak-could not shout her non-consent - that she is to blame, and so the fear that consumes Melinda \#2 definitely stems from her traumatic experience, which represents how woman learn to be on edge, often after something terrible has already occurred.

This culture of fear is again invoked when Melinda attempts to reveal her trauma for the first time. In the section entitled "Communication 101," Melinda tries to warn Rachel about Andy and what he is capable of. As they pass a notebook back and forth, catching up, Melinda finally reveals why she called the police: "I didn't call the cops to break up the party, I write. I called-I put the pencil down. I pick it up again-them because some guy raped me. Under the trees. I didn't know what to do" (Anderson 183, emphasis in original). Melinda avoids using Andy's name for as long as she can, but once she tells Rachel that it was Andy, Rachel refuses to believe her: “'Liar!' ... 'I can’t believe you. You're jealous. You're a twisted little freak and 
you're jealous that I'm popular' (Anderson 184). Rachel's response is, of course, troublesome because she exemplifies a rape culture myth that the victim accuses their rapist for personal gain, which the novel emphasizes. However, the novel never considers how traumatic having Rachel reject her story could be for Melinda. In Asking for It, one of the rape myths that Harding discusses is that the victim has lied about the rape in order to achieve something, usually seen as a way "to get revenge on men who cheat or punch men who didn't call afterwards, or minimize their own shame over saying yes" (25). Rachel's refusal to believe Melinda occurs because she thinks that Melinda has an alternative motive for accusing Andy of rape, and this particular scene reinforces how prominent this type of mythology is.

I would also like to note that, unlike Gabi, Melinda's sexual agency is never called into question by other characters or by herself. Instead, Melinda has silently been judging the girls and condemning several of her classmates, indicating that they are not passive. The most worrying and disturbing of Melinda's judgments are what she has to say about the cheerleaders at her school.

My parents didn't raise me to be religious. ... I think the Merryweather cheerleaders confuse me because I missed out on Sunday School. It has to be a miracle. There is no other explanation. How else could they sleep with the football team on Saturday night and be reincarnated as virginal goddesses on Monday? It's as if they operate in two realities simultaneously. In one universe, they are gorgeous, straight-teethed, long-legged ... In Universe \#2, they throw parties wild enough to attract college students ... They rent beach houses in Cancún during Spring Break and get group-rate abortions before the prom. (Anderson 29-30, emphasis added) 
Her description of the cheerleaders exemplifies how Melinda buys into a harmful societal construction of femininity. Harding describes this phenomenon in which "girls are supposed to be the pure ones, the responsible ones, the ones putting brakes on all adolescent sexual overtures regardless of their own desires" (45). Melinda's comments harken back to a lot of criticism and policing surrounding any woman who chooses to assert her sexual agency in this way, and her attitude in response to these girls is part of the same attitude that makes certain aspects of rape culture possible. The idea that these cheerleaders might assert their sexual agency in this way contrasts starkly with society's desire for them to remain virginal. ${ }^{7}$ It is this stark contrast that often leads to rape myths and victim-blaming that I mentioned earlier when discussing Gabi, $a$ Girl in Pieces. Melinda's judgments represent how enculturated she is in this conceptualization of passivity.

While Melinda's ostracization in school has to do with people not understanding why she called the cops during the summer party (the only person who rejects her statement that she was raped is Rachel because she thinks Melinda is jealous), this view of female sexuality often makes society question whether rape victims really actually want(ed) to be raped. This is especially important to note in the light of Andy's comment when he corners Melinda at the end of the novel: "Rachel blew me off at the prom, giving me some bullshit story about how I raped you. You know that's a lie. I never raped anybody. I don't have to. You wanted it just as bad as I did" (Anderson 193, emphasis added). However, the section entitled "A Night to Remember" opposes

\footnotetext{
${ }^{7}$ Granted, this agency may lead them to unsafe sexual practices depending on their
} sexual education. Melinda's comment about abortions may hint at this, but the novel does not make it clear whether the cheerleaders are educated about the sexual practices that they are engaging in. 
Andy's perspective. Melinda remembers that she "couldn't figure out how to tell him to slow down,” noting “'In my head, my voice is as clear as a bell: 'NO I DON'T WANT TO!' But I can't spit it out" $(134,135$, emphasis added). Melinda never consents to what Andy does to her, yet, the comment still stings enough for the readers to recognize the damage this rape myth does. "[W]ell, they can kiss my ass" and "Let me tell you about it:" How These Novels End and

\section{What That Means}

As Gabi, a Girl in Pieces progresses, Gabi becomes more outspoken, choosing to stand up for herself against the notions of femininity that her mother and aunt attempt to force on her. For a project for her English class, Gabi sets out to make a zine that describes the female body and all the ways a girl could expect her body to change or be manipulated by society. Motivated by her own experience of lacking education and information about her body, Gabi "wanted the zine to make people think about how girls are raised to think about our bodies and who gets to decide how we think about them" (Quintero 198). This self-assertion about womanhood is further exemplified when Cindy reveals that German raped her. Gabi angrily notes, "The whole way home I just kept thinking about what I've heard all my life from my mom and other women whenever boys have done something stupid and/ or wrong: 'Boys will be boys,' and what a load of bullshit that is. I had to write about it" (Quintero 223). So, she writes "Instructions for Understanding What Boys Will Be Boys Really Means" and criticizes all of the things that her mother and aunt and the larger society in general say about what it means to be a boy and, consequently, what it means to be a girl (Quintero 223). However, an appreciation of Gabi's own challenges to those notions of femininity is not possible without considering how Gabi learns to assert herself. 
When Gabi decides to buy condoms, she comments, "I didn’t tell Cindy [about buying condoms] because she would be mad at me, and I would probably get a whole lecture on why sex is bad. She still thinks that what German did was her fault and that that's how boys are" (Quintero 235, emphasis added). The implications of this statement are two-fold. Gabi's final comment about Cindy's understanding of what happened that night implies that Cindy, like society, blames the victim, even though that victim is herself, which is clear since Gabi knows that what German has done is not Cindy's fault. Furthermore, Gabi’s refusal to engage in an important discussion with her best friend about her sexual decisions and how she is an active participant might seem to undercut much of the progress made by Gabi's questioning of the idea that "boys will be boys." However, in the final scenes of the novel, Gabi stands up to her mother when her mother criticizes why Gabi wants to move away for college:

"There are so many temptations out there, Gabi. What if you get pregnant? What if they offer you drugs? Here at least I can keep an eye on you. ¿Pero allá?” I grew some and told her that if I wanted to have sex, I could do it here. That I have already been offered drugs, and I have said no. That she raised a semidecent daughter that she could trust. And that I was moving out and that I would love her support, but either way I had to go. (Quintero 273, emphasis added) Notably, there are more characters reinscribing notions of traditional femininity that make rape culture possible than characters who are questioning these notions; however, the novel emphasizes Gabi's refusal to be passive, and the previously mentioned characters even serve to further stress how strongly she stands up for what she believes in. In the end, she refuses to give into the tenets of femininity that her mother, aunt, and best friend abide by. This point is poignantly driven home by the final line of the novel: "And if anyone has trouble understanding 
that, well, they can kiss my ass" (Quintero 278). As the novel concludes, we are left with a strong and independent young woman who ultimately undermines the indoctrination into passivity that makes rape culture possible and challenges how society reinscribes rape culture, even while it critiques methods of indoctrination along the way.

On the other hand, Speak's discussions of rape imply several problematic things, but the thing that perhaps bothers me the most about Speak is the emphasis that it places on Melinda-a girl — saying no to Andy's - a boy's — second attempt at rape:

The only sound I can make is a whimper. He fumbles to hold both my wrists in one hand. He wants a free hand. I remember I remember. Metal hands, hot knife hands.

No.

A sound explodes from me.

“NNNOOO!!!"” (Anderson 194)

Melinda proceeds to fight back against Andy, grasping a shard of mirror against Andy's face: "I said no," Melinda emphasizes (Anderson 194). We are, of course, expected to read this triumphantly. Melinda has stood up to her attacker; she has taken charge.

I in no way wish to discount Melinda's reclaiming of her own agency. I also want to note that I both respect and recognize the importance of talking about rape in order to bring recognition to the issue. Self-defense is important, and I do not wish to undermine women empowering themselves at all. However, focusing so strongly on Melinda speaking outespecially in relation to non-consent-without ever discussing what happens to Andy or considering Andy's role in these actions is extremely bothersome in terms of the gendered responsibilities in rape prevention. Since we never receive any information about the 
consequences of Andy's actions, we are left to believe that it is the woman's job to speak up and protect herself from rape, as if speaking about the trauma automatically makes things all right. In the description of this scene, the narrative goes on to indicate that Nicole and other female lacrosse players are pounding on the door of the closet that Andy has locked himself and Melinda in, which again emphasizes a community of women fighting back against this issue. Rape, however, is not just a woman's issue, not only because women are not the only ones who can be raped, but also because both boys and girls need to learn that it is not okay to rape.

Furthermore, emphasizing woman's role in retaliating against rape reinscribes notions that women must always be policing themselves. When considering the implications of different campaigns bringing awareness about consent in any sexual activity, Harding details how these campaigns often end up as "messages to men explaining what they already know, and messages to women that avoiding assault is a matter of constant vigilance, uninterrupted sobriety, and a degree of assertiveness that we know will instantly mark us as arrogant bitches" (18). More to the point, though, is that “"A crucial upshot of this rhetorical strategy [of such a focus on consent],' write Hansen, O'Byrne, and Rapley, 'is that the onus for the clear communication of sexual refusal is placed squarely on young women's shoulders'” (Hansen, O'Byrne, and Rapley qtd. in Harding 19). Speak ends by emphasizing that Melinda is the only one responsible for protecting herself against rape. This removes any emphasis on the person who attempts to rape and/or succeeds in raping individuals. Harding boldly asserts that "every American boy is at risk of growing up to become a rapist" because "we live in a rape-supportive culture, and boys have to grow up here, too"- not because of any inherent biological drive to rape, but because they are just as vulnerable to ideologies about rape as girls (37). Therefore, Speak implicitly designates rape as solely a woman's issue. 
Moreover, we can consider the ending of these two novels through Mike Cadden's points about single-voiced and double-voiced discourse in Young Adult novels from his article "The Irony of Narration in the Young Adult Novel." Cadden's main argument about the uses of singlevoiced and double-voiced discourse points to "whether or not the ironist—in this case the young adult author who employs a young adult consciousness in a young adult novel—has a responsibility for how she or he manipulates that unawareness," and he considers how adult power plays out in narratives where an adult ironically utilizes a young adult voice (147). Through this, Cadden points out how single-voiced discourse indicates that only one voice is used in a work to discuss the problems or issues in a novel, while, in double-voiced discourse, "no single position in the text is clearly endorsed or becomes clear at the expense of others, which enables the reader to consider the rightness of the positions based on the specific details of the narrative" (147). According to these definitions, we can understand how Speak is more single-voiced while Gabi is more double-voiced. In the case of Speak, we are primarily presented with Melinda's comments and feelings about her rape. The other characters who talk about this issue — Rachel and Andy, for instance — appear only momentarily. While this, of course, is not inherently problematic, it does mean that some of Melinda's comments — such as her criticisms of the cheerleader's sexual practice—are never called into question. Conversely, Gabi, A Girl in Pieces juxtaposes Gabi's point of view about women and sexual agency with her mother's, aunt's, and Cindy's, which present related but varying views throughout the novel. In doing so, the novel creates more opportunities for conversation than Speak does because it provides alternative viewpoints. Even though both novels are focalized through one character (they are both written in first person), Gabi, A Girl in Pieces poses more questions about what it means to be a woman in the current, dominant society. Moreover, characters' opinions and points of view 
(like Gabi's mother and aunt as well as Cindy's perspective of her own rape) are called into question, and Gabi does not simply accept the facts but continuously reconsiders her position.

Therefore, Isabel Quintero's YA novel, Gabi, a Girl in Pieces, demonstrates how Gabi rejects rape culture's ideologies, especially the idea that women need to police their own bodies and sexuality in order to remain safe from the threat of rape. In discussing Cindy's rape as well as various character's beliefs about sex, sexual agency, and sexuality more generally, the novel considers how rape culture works, especially through indoctrination into passivity. Furthermore, the narrative illustrates how Gabi must reconcile her own sexual desires with her family's desires for her to remain abstinent. Through the conversations surrounding sexual agency, femininity, and rape, the novel undermines a lot of the work that rape culture attempts to do as discussed by scholars such as Kate Harding, Sandra Bartky, Holly Henderson, and Sharon Marcus. Conversely, while Laurie Halse Anderson's Speak reaches some of the goals it sets for itself, there are several moments in the narrative that are troubling. While it stresses how important it is to speak about one's trauma, perhaps in order to seek justice, Melinda's critical assessments of other females in the novel—many of which represent ideologies associated with rape cultureweakens these accomplishments. The reasoning for the narrative to include Melinda's critical assessment of her female classmates is not clear. What is evident, though, is how this weakens the novel's work to call attention to society's damaging responses to rape culture. Since Speak is a single-voiced novel, the audience only receives one viewpoint-Melinda's. Therefore, no other viewpoints can critically engage with what Melinda believes or with what she fears because of her trauma, which leaves the reader with one understanding of rape and rape culture. 


\section{CHAPTER III: THE POWER OF VICTIM BLAMING IN ACQUAINTANCE RAPE SITUATIONS IN CHRIS LYNCH'S INEXCUSABLE AND COURTNEY SUMMERS'S ALL}

THE RAGE

\section{A Cultural Phenomenon: Acquaintance Rape, Victim Blaming, and The Consequences}

In her 2013 book Rape is Rape: How Denial, Distortion, and Victim Blaming Are Fueling a Hidden Acquaintance Rape Crisis, legal scholar Jody Raphael studies acquaintance rape—a specific form of rape that involves a victim being assaulted by someone that they know-and posits how this type of rape often leads to victim blaming and shaming. As Kate Harding and other feminist scholars have noted, a major component of rape culture is that many members of society do not believe rape victims when they declare that they have been raped. Raphael specifically asserts that the related notions of victim blaming and shaming are problematic responses, noting that "Indifferent or punishing responses endemic today toward those claiming rape ... are undoubtedly keeping reporting at low level, confirming rape deniers' assertions of low rape prevalence" (191). Not only are victims afraid to speak out, but also this lack of speaking out forestalls justice and makes it seem as if the crime is not as prevalent as it actually is. Raphael cites in her book how "Research confirms that most rapes are performed by individuals known to the victims" (Raphael 89 , emphasis added). ${ }^{8}$ Since rape committed by a

${ }^{8}$ One study noted that "only 11 percent of rapes were at the hands of strangers" and that, in this study, most reported rapes fell under the category of acquaintance rape (89). Raphael also points out that "An important study ten years earlier found that only 16.7 percent of all women and girls who reported rape to researchers were raped by a stranger; 24 percent of the assailants were spouses, cohabiting partners; and 21.5 percent a current or former date, boyfriend, or girlfriend" (89). 
known assailant is the most common type of rape, we must recognize the power that acquaintance rape holds within rape culture. One particular way of doing this is by recognizing how we construct acquaintance rape and how this construction affects rape culture on a larger scale, especially because of the relationship between acquaintance rape and the practice of victim blaming.

When discussing rape, we must distinguish from rape more generally; by acknowledging that the victim knew her attacker, we can understand why the impact that acquaintance rapists have on their victims beyond that of the physical assault is particularly noteworthy. At this point I want to make very clear that it is not that other instances of rape do not affect the victim beyond the physical assault—psychological trauma is one such example of effects beyond physical assault — but there is an additional nuance to the power dynamics of acquaintance rape that needs to be explored. Notably, many women mistrust the reporting process of what happened because they know their attacker and feel that people will not believe them or they feel that their attacker has more power over how the situation will be viewed. Oftentimes, society members that adhere to rape culture scrutinize victims' stories and seek ways to blame or shame the victim for what occurred.

A major concern that arises when defending an (alleged) rapist is that the victim filed a false report. While false reports do occur, the percentage of false reports that do happen does not necessitate the level of scrutiny that victims receive. Instead, "[i]t is safe- and logical, and ethical - to presume that person is a victim, unless there are specific indications that this is one of the rare false reports" (Harding 62). Unfortunately, a major part of rape culture involves placing rape victims under unfair and grueling scrutiny. I would assert that this emphasis on the victim's reliability is even more prevalent in regards to acquaintance rape. Those who scrutinize 
rape victims may do so in a desperate search to reaffirm the "goodness" of the rapist (even if the evidence contradicts this). If the rapist, for instance, is well known and liked and maintains a good reputation within his community, then friends, family, and peers are more likely to believe his word over the victim's since it may be too hard to see their friend as the violent person that he is. Such power dynamics are at the heart of the individuals who prosecute acquaintance rape because this can often carry over into a rapist's legal defense. Actually reporting rape becomes problematic, then, because of such attitudes and reactions surrounding reporting more generally. Andrew Taslitz in his book Rape and the Culture of the Courtroom even claims that an "overriding theme of female silence as the mark of a good woman expresses itself in numerous variations in our general sexual culture and our conceptions of rape" (19). He further problematizes the backlash against rape victims who decide to speak. "Even after the sexual act," he notes, "a woman who cries rape, who speaks of her violation, her assailed dignity, and her physical and emotional pain, is to be distrusted, for she breaks the rule of silence" (20, emphasis added).

Using the above scholars, this chapter explores acquaintance rape as a particular aspect of rape culture and how it affects female victims. I examine how two YA novels—Chris Lynch's Inexcusable and Courtney Summers's All the Rage-explore the issue of acquaintance rape. Told from her first person perspective, All the Rage follows how Romy Grey must deal with the backlash she receives when she accuses Kellan Turner, the sheriff's son, of raping her one night at a party. Because everyone believes Kellan is a good guy, no one in town believes Romy, and the novel explores how Romy's peers and fellow townspeople shame and blame her, refusing to believe that Kellan raped her (instead believing that what occurred was consensual). On the other 
hand, Keir Sarafian tells his story in Inexcusable, trying to convince himself (and the reader) that he is a good guy and, most importantly, he could never have raped Gigi Boudakian.

\section{Victim Blaming and Shaming: Did She Deserve It? (No. She Did Not.)}

Simply stated, victim blaming and shaming involve finding ways in which the victim is at fault for the rape or ways that the victim should be feel guilty about what occurred. Such practices are compounded by various institutions' refusal—such as families, school, legal situations, and so forth - to believe victims' statements. Taslitz notes how, in the legal system, "we demand corroboration [of rape] in the form of physical evidence of force, prompt report, eyewitnesses, and tributes to pure character. Yet, the majority of rape cases leave no wounds, not even bruises or scratches" (6). ${ }^{9}$ Rape victims' statements are never just simply believed; their bodies must also corroborate the image of rape that society perpetuates. As Harding asserts, 'Rape culture encourages us to scrutinize victims' stories for any evidence that they brought violence upon themselves - and always to imagine ourselves in the terrifying role of Good Man, Falsely Accused, before we 'rush to judgment"' (Harding 3-4). Rape culture emphasizes, in these cases, the good nature of the rapist and the bad nature of the victim. While neither All the Rage nor Inexcusable deals directly with court systems, they do reflect this attitude or mindset- that the victim must check off certain boxes in order to be considered a proper victim. In both novels, other characters scrutinize the female protagonists when they talk about their rapes. Compared to Inexcusable, we see victim blaming and shaming in more deliberate and malicious ways in All

\footnotetext{
${ }^{9}$ Contextualizing rape in terms of force is an issue, too, since as Taslitz notes, rape does
} not always show evidence of such force. Harding states that "it was only in 2013 that the word 'forcible' was struck from the definition of rape in the FBI's Uniform Crime Reporting program" (126-7). 
the Rage since it examines the aftermath of Romy's accusation and how her peers condemn her. However, Inexcusable also considers the part that victim blaming plays in rape culture by emphasizing how Keir responds to Gigi when she states that he raped her.

Victim scrutiny often manifests in several different ways. Taslitz points out that there always seems to be an ulterior motive for women to cry rape: "With rape, the victim's truthfulness is almost always challenged: she is covering a pregnancy, hiding an affair, seeking revenge for advances spurned. Or the problem is her character: a slut, drug addict, 'nut' case, or congenital liar" (Taslitz 6). ${ }^{10}$ The quality of a victim's character emphasizes another issue of rape culture since victim blaming often reinforces problematic notions of gender. Carine Mardorossian acknowledges in her book Framing the Rape Victim: Gender and Agency Reconsidered that "Women are now repeatedly accused of triggering if not of causing rape through their misguided behavior (drinking, partying), their indoctrination (by a feminism whose representation of women as victims is blamed for producing their victimization), or their own lack of will (which allegedly leads to a complicit passivity)" (2). Thus, it seems that woman can never be blameless when it comes to rape.

From the very beginning of All the Rage, the readers know that Romy has been raped by Kellan: the inside flap of the book of the hardcover edition tells us this, and the first scene of the novel provides the moments leading up to Romy's rape. Therefore, the reader is not supposed to question whether what Romy states is true or not; rather, the novel automatically positions the reader to believe Romy and her story. However, Romy's peers and the other citizens of Romy's hometown, Grebe, refuse to believe Romy. Her peers denigrate her repeatedly for what they

${ }^{10}$ The term "cry" is a problematic description, but in order to acknowledge the context, I have chosen to use "cry" in this instance. 
believe are her lies. When Romy goes to the gas station to get gas with her mother, Alek, one of her classmates, writes "SLIT" in the dust of Romy's mother's car: "Because 'slut' was just too humanizing. A slit's not even a person. Just an opening" (38). The linguistic assaults repeatedly continue at school as her classmates emphasize the so-called lie she told about Kellan $(46,53)$. This repeated insistence of Romy's inability to tell the truth harkens back to what Harding, Taslitz, and Raphael note as rape culture's unwillingness to trust the victim.

Victim shaming continues in All the Rage through the degrading techniques Romy's peers employ. Later in the novel, a customer upsets Romy at her work, and Romy runs off to an annual and notorious party held at a nearby lake by the high school students. The next morning someone discovers Romy in the middle of the road with her shirt unbuttoned and her body battered. When an officer brings Romy back home and Romy goes to take a shower, she notices, "The red on my body—letters. Letters on my skin, reversed in the glass, turning themselves into this-RAPE ME" (112). The narrative does not explain until much later how Romy wound up in the middle of the road. At the party, Romy's classmate Brock drugged Romy with GHB; wrote on her body with her lipstick; had the younger brother of Romy's rapist, Alek, take pictures of her; and then took her body to the middle of the road where Romy believes he was going to rape her. However, Sheriff Turner simply wants to dismiss what happened: "It was a practical joke ...Romy was unconscious and unresponsive the entire time" (302). Turner speaks as if being unconscious and unresponsive makes the violation of her body even more acceptable. As Turner talks, Romy connects the words that Brock wrote on her stomach after drugging her with the idea that "my shirt, still undone after the lake? Laid wide open for him. Rape me. 'He was going to rape me,' I say" (303). Since victim blaming is a result of denial and often assumptions about the victim's supposed ulterior motives, Turner believes that Romy is seeking attention. When Romy 
repeats that she believes that Brock was going to rape her and that another girl, Penny, was trying to stop him, Turner explodes. "I have never seen anyone so desperate for attention in my life," Turner shouts to Romy and her mother (304-05). Unfortunately, we can predict Turner's outburst not only because he represents the very notions of rape culture that Harding, Taslitz, and Raphael have described but also because this is not the first time that Romy has been humiliated and ridiculed by Sheriff Turner.

When word first gets out that Romy said that Kellan raped her, Romy finds herself face to face with the town's sheriff, who is additionally the father of her rapist. When Sheriff Turner appears at her home to confront her, he states that Romy's father "said my son raped your daughter...of course, no one believes it but that still doesn't mean he can go around saying it. I want to know why he's saying it" (96, emphasis in original). The conversation quickly devolves into an examination of Romy's role in the rape. Harding discounts the idea that a victim "wanted it," that her rape is somehow related to her sexuality, demeanor, or clothing choice, when she states that "It is literally impossible to ask for rape. Rape, by definition, is sex you did not ask for" (24). Unfortunately, the excuse "She asked for it" or "She wanted it" is still used by rapists and skeptics, such as Sheriff Turner, in order to deny the fact that someone raped someone else. Sheriff Turner emphasizes his doubts when he uses Romy’s rumored crush on Kellan against her to try to prove why Kellan could not have raped Romy. As Turner continues to interrogate Romy and her mother, he says, "they say you chase after him [Kellan]. That you wore an outfit, hoping that you would catch his attention. Short skirt, skimpy shirt. ... And, reaching into his pocket, unfolding a piece of paper, tell me about what you wrote in this email here: Penny, I want him. I dream about him” (97, emphasis in original). The sheriff uses Romy’s desire against her, even though Romy was too intoxicated to legally consent when the incident occurred. When critiquing 
the emphasis that society puts on women to protect themselves, Harding points out that: "It keeps our focus on what the victim did 'wrong' instead of on what type of person rapes, or how he chooses his victims, or how we can prosecute sexual assaults more effectively. It trades on reductive, sexist ideas about how 'good' and 'bad' women behave and strongly suggests that some victims, frankly, had it coming" (33). Sheriff Turner's refusal to believe Romy emphasizes Harding's point since Romy's accused rapist is his son, and, because of this relationship with Romy's accused rapist, the sheriff seeks any opportunity to refute what she says - to place the blame on her. Sheriff Turner goes on to insinuate that what happened between Romy and Kellan cannot be called rape because on some level (he believes) Romy was complicit:

Now maybe they fooled around and maybe she was a little too drunk at the time, but rape? You can't just call it something like that.

Then what do you call it?

He says, nobody believes it. They think it's ugly. I think it's ugly.

He says, I hope we can get this sorted out before you make it worse for yourselves (Summers 97, emphasis in original).

Turner's failure to accept what his son has done leads him to believe Romy's attraction to Kellan is reason enough for what occurred to not be considered rape. Consequently, all of Turner's bullying keeps Romy from reporting Kellan to the legal authorities, especially because Turner is the legal authority.

In Lynch's Inexcusable, victim blaming happens because Keir will not submit to Gigi’s plea for him to admit what he has done. "Miscommunication," Keir tells Gigi, "is all that really happened here, that's all. I thought one thing, you thought another thing. Why do you have to make it worse? Carl [Gigi's boyfriend] has been my friend forever, just like you have been my 
friend forever, so why do we have to make an accident into something else? I love you, Gigi” (Lynch 24, emphasis added). As Keir's use of it suggests, the concept of miscommunication is often used to displace blame from the rapist onto the victim. Harding points out that "[Deborah] Tannen and [John] Gray's runaway success [with You Just Don't Understand Me: Women and Men in Conversation and Men Are from Mars, Women Are from Venus, respectively]" emphasized this idea of miscommunication, since they "helped to lay the cultural groundwork for a simplistic dangerous understanding of what causes acquaintance rape" (13). Inexcusable represents the popularity of such a myth because it shows how vehemently Keir wishes to believe there was a miscommunication. "[M]iscommunication theory," Hannah Frith and Celia Kitzinger note, "is used to argue that rape and other forms of sexual abuse are often the outcome of 'miscommunication' between partners," meaning that "he misinterprets her verbal and nonverbal communication, falsely believing that she wants sex" and that "she fails to say 'no' clearly and effectively" (qtd. in Harding 518). For Keir, this is what he believes has occurred. The first person narrative structure further reinforces the idea that Keir simply missed the clues to Gigi's non-consent because Keir's perspective is the only one provided. When Keir finally describes how he raped Gigi, he is clearly delusional:

It was all right to kiss her lips. It did not seem all right not to kiss them. I kissed

Gigi Boudakian there on her lips first lightly as if I did not want to be known, then harder and realer like I definitely did.

Her lips were so soft I could have fallen right in. I would have loved to.

But the glory of it was that she kissed me back. (Lynch 159, emphasis added) While we are supposed to read this scene knowing that what is happening is not consensual (since we have known from the beginning that Keir rapes Gigi), it is still disturbing to read this 
scene through the eyes of a rapist who wholeheartedly believes that she wanted him to kiss her or that what she wanted was miscommunicated in some way.

Additionally, Keir repeatedly blames Gigi for what happened in an attempt to displace his guilt. "You have to talk to me, Gigi," Keir tells her; "If people don't talk to each other, then they get everything wrong. You have got everything wrong," again emphasizing that what happened was merely a mistake (85). In these lines, Keir again insists that there was a miscommunication between the two of them. Keir goes on to tell her, "You hurt me, you know, Gigi. That's right. You're the one who punched me and scratched me, and I would never, ever even think of doing anything like that to you" (85). In an attempt to dissuade her of his guilt, Keir even goes so far to emphasize how Gigi misreads physical assaults. Finally, Keir declares, "You don't have to be afraid of me, because I have never hurt you and I would never hurt you, and I'm not even keeping you here so that whole window thing was just crazy" (85, emphasis added). Because Keir can only blame Gigi for what happened, he can never own up to his actions.

\section{Considering Him: Acquaintance Rapists and Their Power}

Victim blaming is further complicated in the novels by the depiction of the acquaintance rapists. While both novels portray how the acquaintance rapist exercises power over his victim and the portrayal of the rape more generally, they also both attempt to undercut the "good guy" image often invoked for the rapists in such cases. When discussing why rapists "escaped prosecution," Raphael posits that:

The answers may lie, in part, in their [the rapists'] choice of victim and in their relative abnegation of gratuitous violence. By attacking women within their social networks — so-called acquaintances—and by refraining from the kind of violence likely to produce physical injuries, these young men create "cases" that women 
are least likely to report and that prosecutors are less likely to prosecute. (90, emphasis added)

Raphael's statement suggests that these kinds of rapists, by choosing victims that they know, may preemptively set up situations that can potentially encourage victim blaming or shaming simply based on the social connection between rapist and victim. Even as the novels may not directly discuss either rapists' motivations in selecting his particular victim, they both represent how such power dynamics affect responses to such situations.

Kellan Turner, in All the Rage, is only ever described in flashbacks; he plays no physical role in Romy's day-to-day life after the rape. However, his influence is inescapable. In many instances of rape, if the victim feels that the evidence of the rape seems to be lacking in any regards but most especially in relation to the attacker's character (e.g., whether that individual is believed to be capable of rape or not) or in relation to physical evidence (e.g., the despicable yet common statement that real rape is physically brutal or leaves a victim looking a certain way), then the victim is less likely to report the rape. ${ }^{11}$ In All the Rage, Kellan's character is repeatedly invoked to attempt to show how he is a "good guy" and thus incapable of raping Romy. The first description we read of Kellan is that: "He waits. He waits because he's a nice boy. A blessed boy. He's on the football team. His father is the sheriff and his mother sits at the top of a national auto supply chain and they are both so proud" (Summers 5-6). Romy's classmates are outraged

${ }^{11}$ Harding notes that U.S. Senator Bill Mapoli, when discussing what is an appropriate reason for allowing an abortion in the case of rape, states that "A real-life description to me would be a rape victim, brutally raped, savaged ... She was brutalized and raped, sodomized as bad as you can possibly make it" (Mapoli qtd. in Harding 137). Mapoli's statement delegitimizes other, less brutal, but very real forms of rape, which Harding rightly takes to task. 
for Kellan, who we are led to believe had to leave the town because of Romy's accusations (49). However, no matter how Romy's peers or Sheriff Turner try to make the rape look consensual, Romy's flashbacks directly contradict this image and ultimately reveal Kellan as the rapist that he is.

In order to best exemplify this, I would like to utilize two lengthier quotes. Please note that the italics signify what Kellan says to Romy as he assaults her:

He waits until he can't wait anymore. ...

Look at me, look at me, hey, look at me.

He wants her to look at him....

He explores the terrain of her body while he pretends to negotiate the terms.

You want this, you've always wanted this and we're not going that far, I promise. (Summers 5-6)

Kellan reasserts his power over Romy by repeatedly asking her to look at him. In her article "Fighting Bodies, Fighting Words: A Theory and Politics of Rape Prevention," Sharon Marcus points out how "most rapists take verbal initiatives with their targets in addition to deploying physical aggression" (371). Kellan reaffirms his physical assault with his repeated insistence that Romy look at him. Marcus also notes that "many [rapists] speak a great deal during the rape and demand that the women who they rape either talk to them or recite particular phrases" (371). While readers do not see Kellan ask Romy to repeat anything, the portrayal of his own linguistic assault emphasizes Kellan's power over Romy. At the same time that Kellan commands Romy to look at him, he insists that Romy wants the sexual encounter as much as he does.

Later in the novel, we get the full scope of what Kellan does to Romy: He covers her mouth. 
That's how you get a girl to stop crying; you cover her mouth until the sound dies against your palm.

He says, okay? Okay.

When he's sure she's going to be quiet, he lets her breath again.

He tells her, it's okay.

... She closes her eyes again. He makes her open them. Wake up, wake up. Wake

up because you want this, you've always wanted this. But she didn't want this.

She doesn't want this. He forces himself inside her. She's tight and she's dry.

It hurts.

Open your eyes.

But it hurts.

Open your eyes. (Summers 272-3)

The sharp contrast between these scenes and the novel's beginning description of Kellan as well as Romy's peers' insistence that she is lying about Kellan raping her forces many issues associated with acquaintance rape to the surface of All the Rage. The novel's depiction of Kellan through Romy's point of view undermines all of the good things that Romy's classmates and family want to believe: the myth of this rapist's goodness is destroyed.

Since Inexcusable is told from Keir's point of view, part of the reader's experience may involve defamiliarizing themselves with depictions of rape in YA narratives because the narrative positions us to take on a rapist's point of view rather than the victim's. As with Kellan, the novel starts out by establishing that Keir is a good person: "You could ask pretty much anybody and they will tell you. Rock solid, Keir. Kind of guy you want behind you Keir Sarafian, straight shooter. Loyal, polite. Funny. Good manners. He was brought up right, that boy was, is 
what you would hear. ... I am a good guy" (Lynch 3, emphasis in original). However, such an emphasis on Keir deemphasizes Gigi's experiences. Keir repeatedly uses his character to explain "the wrongness of this situation," stating, "I have character witnesses. Because I have character. I have two brainy, insightful older sisters, Mary and Fran, who brook no nonsense off anybody, and Mary and Fran love me to pieces and respect me, and they would not do that if I were capable of being monstrous" (4). In order to undermine Keir's statements, the novel ultimately positions Keir as an unreliable narrator, which suggests that we should mistrust everything Keir says. Despite his repeated attempts to exemplify his good character, we are still supposed to question these declarations. Keir as the "good guy" is opposed later in the novel with a Keir that desperately wants Gigi to take back what she said about him raping her. When Gigi tries to leave after Keir has been pleading with her to admit that he did not rape her, "Quick as a snake [Keir] reach[es] out and around her and seize[s] the window frame and Gigi Boudakian at the same time," refusing to let her go (84). This force is at odds with the Keir that Keir himself projects and wants us to know. Yet, we recognize that Keir is not the "good guy" he suggests he is because he is an unreliable narrator who clearly frames situations in order to present a better image of himself, which the repeated assertions of his character suggest. Furthermore, Keir tells the readers that "I thought about mistakes I had made in the past. I thought about when things went wrong. And I realized it was never an issue of intent, but of intensity. I was a good guy, recall" (113-4, emphasis in original). We are supposed to connect to the fact that Keir rapes Gigi and that his intent is not to do so, and we are also supposed to recognize that Keir's statement is probably unreliable. In the end, we know that, regardless of intent, Keir does rape Gigi. 


\section{Reporting... and Its Consequences: The Work These Novels Do and Why It Matters}

Kellan and Keir — these so-called "good guys" — are revealed throughout these novels as the criminals that they are, and the novels leave us with some hope for justice as the novels portray reporting in different ways. While reporting rape to authority figures is only discussed briefly in these novels, the idea of speaking out is a crucial part of the ending of each novel, and such moments undermine the "good guy" image frequently invoked in acquaintance rape situations. Part of what makes reporting so difficult is that rape culture perpetuates the idea that "true speech by a woman is so unusual that it is to be greeted with suspicion and with presumptions of lies based on nefarious motives rather than acceptance" (Taslitz 20). The question can often become, for victims, "Is reporting worth it?" Despite this, All the Rage and Inexcusable vehemently oppose the idea that the victims have nefarious motives when they insist on the truth inherent in the victims' respective statements about their rape. Notably, Romy, who suffers so much from her community's scrutiny, does not initially report her rape to the legal authorities. Having been bullied previously by the Sheriff, Romy's refusal to put her trust in him is not unfounded. Romy only decides to report Kellan at the end of the novel because she hears that Kellan has raped another girl. Penny, Romy's previous best friend, tells Romy that "There was this girl [in another town called Godwit]— she came up to me ... She saw me with Kellan. She told me it wasn't safe to be alone with him. She wouldn't say why, but the look on her face..." (Summers 90, ellipsis in original). When Romy refuses to acknowledge the implications of what Penny is saying, Penny says, "You didn’t report it. You can still report it. ... I looked it up. You still have time. If you do it—something would have to happen” (Summers 90). While Romy refuses to do anything then, the novel ends with Romy asking her classmate Tina (after Tina begs Romy's forgiveness for not believing her when Romy said Kellan raped her) to help 
her find the girl in Godwit that Penny was talking about. Romy's desire to report what happened to her is strengthened by her knowledge that Kellan violated someone else, and the novel emphasizes that this validates Romy's experiences.

On the other hand, Gigi does not report what happened to any legal authorities, but she immediately vocalizes her trauma and does not accept Keir's protests. When Keir tries to understand why Gigi is upset, he asks, "Why does Carl [Gigi's boyfriend] have to come, Gigi? I don't understand at all. And your father, and my father, and everybody" (Lynch 23). While legal authorities are not on their way, we can now presume that an authority figure will investigate what happened because Keir's plea suggests that Gigi has already set in motion some sort of reporting. The narrative does not mention legal consequences, but, in some way, the whole novel puts Keir on trial. While he tries to convince himself and the reader that he is a "good guy" and that he did not rape Gigi, the narrative ultimately illustrates that Keir unreliably narrates what happened with Gigi. ${ }^{12}$ Gigi, however, has no qualms about reporting Keir. Gigi later reminds Keir, "Today Carl is coming, Keir. And so is my father. So is everybody, coming for you, Keir Sarafian" (Lynch 122, emphasis added). The novel ends with Keir realizing what he has done to Gigi, and she tells him (in different terms) that he will have to deal with the consequences of his actions.

Harding sums up quite well why studying the ways in which literature discusses rape culture is important: "The fact is at least one in five women and one in seventy-one men will be

${ }^{12}$ In a different part of the novel, Keir's sister Fran even says, "The way you make things look is not the way they really are, Keir" (Lynch 150). If the reader does not notice the specific places that Keir's narration seems undependable, then statements like this signal to the reader that we should not automatically trust what Keir tells us. 
raped in their lifetimes. The fact is most rapists are known to their victims. The fact is rapists rape deliberately and repeatedly, not because they like sex, but because they like rape" (Harding 25). These novels work to undermine the systems in place that make reporting hard, especially for victims of acquaintance rape. With that said, I would like to make one note, though, about the potentially tricky way that Inexcusable ends.

In the last few pages of the novel, Keir attempts to kiss Gigi again so that she will see that what occurred between the two of them was a simple misunderstanding. When Gigi does not respond, Keir finally sees himself the way that Gigi sees him:

I am horrified. I am sick. I pull away, jump up. I back away from her, all the way across the room from her, and she doesn't so much as blink. I fall onto my bed, let myself go flat and lifeless. I turn over on my side, looking in her direction, and I curl into a tighter and tighter coil. ... I roll onto my other side, face the cinder block wall, and wait for whoever is going to come for me. (Lynch 165) My initial reaction is to question whether this remorse is supposed to undo Keir's crime or to undermine the fact that Keir's entire response to Gigi's valid outcry is that there was a serious miscommunication between the two. Despite all of the work that Lynch's novel seems to do in order to undermine problematic assumptions in rape culture, it reinforces, in these moments, the idea that miscommunication can be a cause of rape. Perhaps Gigi calling her father, boyfriend, and Keir's father after Keir rapes her is supposed to indicate to us that justice will be served. However, emphasizing Keir's feelings about what he has done does little to make up for one hundred and sixty plus pages of his insistence that Gigi wanted it. While the novel's focus on miscommunication and misrepresentation on some level may be an attempt to undermine Keir's narrative reliability, it reinforces a dangerous ideology of rape culture. "This is the problem," one 
chapter begins; "This is what Gigi does not understand. Things have conspired to cloud her mind," Keir tells us (68). "She's not a drinker, Gigi," he notes, referencing earlier when they had been drinking; “Some people shouldn’t drink. It is understandable, but she has just got it wrong. Some of it is cloud, some of it is misunderstanding, but all of it is wrong, and all of it can be straightened out. It has to be straightened out" (68, emphasis added). The emphasis on what occurred is not placed on Keir but on Gigi and what Gigi did. Keir cannot separate his actions from his belief that Gigi was somehow complicit or deliberately involved in what occurred. Moreover, I do not think that this remorse is a successful attempt to show the consequences of Keir's actions. First, we do not receive any information about the legal ramifications for his reactions — only the threat of legal ramifications. Second, the novel ends with the emphasis on Keir, with his remorse and self-loathing, but with no comment on whether Gigi will receive the justice that she should. We can perhaps attribute this to the fact that the novel is told from Keir's perspective. Together, though, Keir's perspective and the final emphasis on Keir's remorse make for a problematic reading of rape culture. As Harding notes, "When it comes to rape, if we're expected to put ourselves in anyone else's shoes at all, it's the accused rapist's" (4, emphasis added). Inexcusable asks us to do just that.

Despite this, Inexcusable works to deconstruct the idea that the supposed "good guy" cannot possibly be a rapist. All the Rage, too, destabilizes the complex issues surrounding acquaintance rape and victim blaming and shaming. Furthermore, these two YA novels rigorously challenge the victim blaming and shaming often connected with acquaintance rape that frequently undermines rape victims' experiences. As they recognize the female protagonists' respective outcries, they challenge the assumptions that rape culture encourages about victims, 
instead focusing on the truth of what happened to these victims. While Romy's and Gigi's voices may be questioned, they persevere and refuse to remain silent. 


\section{CHAPTER IV: CONCLUSION}

As many scholars have established, literature — and especially young adult literature, as is the case for my thesis - teaches in expected and unexpected ways. Literature interpellates its readers into specific ideological positions, so we have to consider all the ways that YA literature especially does this. We must think about both the explicit and implicit ideologies at work in these texts. In a pivotal study of young adult literature, Roberta Trites notes that, "in the adolescent novel, protagonists must learn about the social forces that have made them what they are" and that adolescents in such novels must also "learn to negotiate the levels of power that exist in the myriad social institutions within which they must function" (3). Thus, if YA lit teaches teenaged readers to grow up and be an adult, the figures in any YA novel then represent how to grow up and not to grow up.

Because the texts I have chosen for my thesis examine a topic that some may want to discuss with young adults, much of my analysis, and the conclusion to my analysis, adopt the position that people - more specifically, I imagine parents and teachers - use these texts to inform young adults about rape culture, rape, and related trauma. Cleveland and Durand's study of YA literature that addresses sexual assault points to how often YA texts are used to instruct and discuss with students about the issue and, furthermore, how often we think that YA texts should be used for such purposes. Moreover, Cleveland and Durand's study specifically suggests ways in which teachers can implement such materials in their class, noting that "YAL[iterature] has the potential to serve as a valuable resource for shedding some light on sexual violence and critically engaging adolescents on this relevant issue" (n.p.). It is therefore imperative that we also consider exactly how YA literature can teach its audience and what the ethical implications for this instruction are. 
Part of considering these books in this way, then, also means dealing with the fact that they all consider what a large portion of society believes is a taboo topic. Our reluctance to talk about sex and sexual education with younger audiences can carry over into conversations about rape and sexual assault. I would like to even note that the countless raised eyebrows of anyone who has asked me about my thesis as well as the reluctance of many to talk about this topic point to how taboo the topic is. Likewise many adults worry about what young adults are reading. For instance, the ALA lists Speak on its "Frequently Challenged Young Adult Books list." While Inexcusable and All the Rage do not show up on this list, their respective authors-Lynch and Summers — do for other works. However, if, as Cleveland and Durand posit, we can use literature to talk about such serious topics, then we cannot be surprised when it spurs conversation outside of simply considering it as literature. Banning books like Speak (and, by extension, books like Gabi, A Girl in Pieces, All the Rage, or Inexcusable) only forecloses important and necessary conversations about sex, sexuality, sexual assault, and rape, all topics that these books cover.

With this in mind, my analysis of the four YA novels in this thesis argues that these texts exist within the larger conversation surrounding rape culture as a way for us to understand how YA literature provides information about rape and rape culture to its intended audience. While the temptation in such a analysis could be to affirm that one book is good and another is terrible when addressing rape culture, I want to make it clear that I do not recommend remaining in this standpoint, especially because I do not want anyone to think that this means one text should be read rather than another. If we ignore certain books at the expense of others, we are missing an essential part of the conversation. While it is true that, with my analysis, I hope to clarify these books' individual strengths and weaknesses, it is also true that I hope my analysis opens the conversation further, rather than forestalling conversation so that we can then move away from 
the idea that any of these texts are wholly "bad" or wholly "good" and instead move toward appreciating what each has to offer in order to more holistically understand and interrogate rape culture.

I want to conclude by summarizing how each novel in this thesis participates in the larger discussion of rape culture currently occurring. I especially want to think about how the discourses of each novel prompt reader reflection by examining them through Mike Cadden's framework of ironic narration that he outlines in "The Irony of Narration of the Young Adult Novel." Here, Cadden argues that "Novels constructed by adults to simulate an authentic adolescent's voice are inherently ironic because the so-called adolescent voice is never-and can never be-truly authentic" (146). In such cases, "[T] he YA novelist often only speaks from the position of the young adult but also often believably presents that incomplete growth to awareness without challenge from within the text" (146, emphasis added). Cadden further analyzes this phenomenon in YA texts by using Bakhtin's discussion single-voiced and doublevoiced discourse in order to posit that "Double voiced discourse, achieved through providing multiple and equal YA consciousnesses and a clearly unreliable singular YA consciousness, provides the YA audiences the tools to grow as readers" (153). Such novels, he believes, are more ethical because they provide the reader with the necessary conditions to think about the topic at hand. Cadden's framework thus provides a way of analyzing the type of discourse Speak, Gabi, A Girl in Pieces, All the Rage, and Inexcusable each individually employ.

Most notably, Speak is one of (if not) the first novels to talk about rape and the accompanying trauma, and my analysis (however much it may criticize the text's troublesome moments) cannot and should not take anything away from what it first accomplished. Significantly, Speak provides a way to contemplate how rape culture creates a system in which 
someone may feel that they cannot speak about their trauma. Moreover, Melinda represents the countless victims that rape culture further oppresses by shaming and silencing them. With this said, Speak seems to be a novel employing more single-voiced discourse than double-voiced discourse. The novel generally encourages the reader to take Melinda's point of view without question. While this is not inherently bad, it does mean that, in other moments where Melinda presents problematic ideologies, the reader is not as encouraged to question her comments, which can leave the reader with a problematic reading of femininity and sexual agency.

With the broadening of rape as a topic in Young Adult literature, new narratives provide even more ways to approach this subject. Gabi, a Girl in Pieces specifically tracks Gabi reassessing her own ideologies about women, sexuality, and sexual agency. Because Gabi must confront her mother's, aunt's, and friend's ideologies about what it means to be a woman, especially when expressing her sexuality, I suggest that this novel invokes more double-voiced discourse than single-voiced discourse. While the novel is told in first person point of view through diary-like entries, which typically lends a limited understanding of the events of the novel, Gabi records several conversations with her mother, aunt, and best friend Cindy that provide an additional component to the conversation about rape culture at the forefront of the novel. For all its faults, Inexcusable encourages the reader to assess her or his understanding of what a "good boy" looks like, demystifying the idea that a "good boy" can never be a rapist. Of the novels discussed in this thesis, Inexcusable is the closest to the definition of a novel that employs double-voiced discourse (consequently meaning that it is ethically written) that Cadden defines since Keir is an extremely unreliable narrator. Even as the narrative may encourage us to give Keir the benefit of the doubt since it is told from his point of view, Gigi's voice repeatedly undercuts his ideologies and assists the reader in critically engaging with the serious topic at the 
heart of the novel: acquaintance rape. Additionally, All the Rage takes the trouble of speaking, which is at the heart of Speak, even further, portraying Romy's bullying and shaming in an even harsher light. Like Speak, though, All the Rage uses single-voiced discourse more than doublevoiced discourse since the narrative encourages the reader to believe Romy from the moment that the reader picks up the book. (The back cover of the paperback version of the book says that "All the Rage examines the shame and silence inflicted upon young women in a culture that refuses to protect them.”) Despite the single-voiced nature of the narrative, the novel juxtaposes several voices to Romy's, such as her classmate Tina, her classmate and rapist's brother Alek, her rapist's father who is also the town's sheriff, to complicate the novel's main theme.

My analysis creates a space for us to critically consider what YA texts are trying to accomplish, what they actually accomplish, and how we reconcile these two - and this is the most important part—without banning, challenging, or censoring material because it does not do what we want or expect it to. While Melinda's criticisms of her classmates in Speak bother me, the novel, like the other novels examined here, has a lot to offer because we can still consider how these differing narratives represent specific aspects of rape culture. Because they each illustrate something different, I think it is extremely important to advocate for reading a variety of books that address this issue. One book cannot cover everything. My analysis outlines the strengths and weaknesses of each book in order to analyze better what exactly is at stake in such novels. Moreover, by understanding these differences, we can better utilize them...if we are using them to discuss rape and culture that enables it. 


\section{WORKS CITED}

Altrows, Aiyana. "Rape Scripts and Rape Spaces: Constructions of Female Bodies in Adolescent Fiction." International Research in Children's Literature 9.1 (2016): 50-64. Web. <http://www.euppublishing.com/doi/pdfplus/10.3366/ircl.2016.0182>

Anderson, Laurie Halse. Speak. 1999. New York: Square Fish, 2011. Print.

Bartky, Sandra. "Foucault, Femininity, and the Modernization of Patriarchal Power." The Politics of Women's Bodies: Sexuality, Appearance, and Behavior. Ed. Rose Weitz. N.p.: n.p., 2008. 25-45. Web. <http://faculty.uml.edu/kluis/42.101/Bartky_FoucaultFeminityandtheModernization.pdf>

Cadden, Mike. "The Irony of Narration in the Young Adult Novel.” Children's Literature Association Quarterly 25.3 (2000): 146-154.

Cleveland, Erika, and Sybil Durand. "Critical Representations of Sexual Assault in Young Adult Literature."The Looking Glass: New Perspectives on Children's Literature 17.3 (2014): n. pag. Web. 30 Oct. 2016.

<https://www.lib.latrobe.edu.au/ojs/index.php/tlg/article/view/545/487>.

"College Girl." SUNY Press. State University of New York Press, n.d. Web. 01 Nov. 2016. <http://www.sunypress.edu/p-5672-college-girl.aspx>

Deutsch, Lindsay. "Columbia student to carry mattress until alleged rapist leaves campus." USA Today News. Gannett Satellite Information Network, LLC, 3 September 2014. <www.usatoday.com/story/news/nation-now/2014/09/03/emma-sulkowitz-columbiarape-performance-art/150012777/> 
Fantz, Ashley. "Outrage over 6-month sentence for Brock Turner in Stanford rape case." CNN US Edition. Cable News Network, 7 June 2016. <www.cnn.com/2016/06/06/us/sexualassault-brock-turner-stanford/>

Harding, Kate. Asking for It: The Alarming Rise of Rape Culture--and What We Can Do about It. Boston: De Capo, 2015. Print.

Henderson, Holly. "Feminism, Foucault, and Rape: A Theory and Politics of Rape Prevention." Berkeley Journal of Gender, Law \& Justice 22.1 (2007): 225-53. Berkeley Law Scholarship Repository. Web. <http://scholarship.law.berkeley.edu/bglj/vol22/iss 1/7>

Lynch, Chris. Inexcusable. New York: Atheneum for Young Readers, 2005. Print.

Marcus, Sharon. "Fighting Bodies, Fighting Words: A Theory and Politics of Rape Prevention." Theorizing Feminisms: A Reader. Ed. Elizabeth Hackett and Sally Haslanger. New York: Oxford UP, 2006. 368-81. Print.

Mardorossian, Carine M. Framing the Rape Victim: Gender and Agency Reconsidered.

Piscataway: Rutgers University Press, 2014. Ebook Library. Web. 04 Aug. 2015.

Mills, Claudia. "Heeding Rousseau's Advice: Some Ethical Reservations about Addressing Prejudice through Children's Literature." Ethics and Children's Literature. Ed. Claudia Mills. Surrey: Ashgate, 2014. 181-193. Ebook Library. Web. 18 Aug. 2016.

---. Introduction. Ethics and Children's Literature. Ed. Claudia Mills. Surrey: Ashgate, 2014. 112. Ebook Library. Web. 18 Aug. 2016.

Moran, Mary Jeanette. "Making a Difference: Ethical Recognition through Otherness in Madeleine L'Engle's Fiction.” Ethics and Children's Literature. Ed. Claudia Mills. Surrey: Ashgate, 2014. 75-88. Ebook Library. Web. 18 Aug. 2016. 
Peters, Patricia. "Frequently Challenged Young Adult Books." American Library Association. American Library Association, Aug. 2016. Web. 07 Mar. 2017. <http://www.ala.org/bbooks/frequentlychallengedbooks/YAbooks>.

Quintero, Isabel. Gabi, a Girl in Pieces. El Paso: Cinco Puntos, 2014. Kindle ebook file.

Rana, Marion. "Sexual Violence and Rape Myths in Contemporary Young Adult Fiction." Politics and Ideology in Children's Literature. Ed. Marian Thérèse Keyes and Áine McGillicuddy. Dublin: Four Courts Press, 2014. 168-178. Print.

Raphael, Jody. Rape is Rape: How Denial, Distortion, and Victim Blaming Are Fueling a Hidden Acquaintance Rape Crisis. Chicago: Lawrence Hill Books, 2013. Print.

Summers, Courtney. All the Rage. New York: St. Martin's Griffin, 2015. Print.

Tarr, Anita. "The Absence of Moral Agency in Robert Cormier's The Chocolate War.” Children's Literature 30 (2002): 96-124.

Taslitz, Andrew E. Rape and the Culture of the Courtroom. New York: New York U Press, 1999. Print.

Trites, Roberta Seelinger. Disturbing the Universe: Power and Repression in Adolescent Literature. Iowa City: University of Iowa Press, 2000. Print. 